\section{Effects of citric acid and fibronectin and laminin application in treating periodontitis}

\author{
B. Smith', R. Caffesse', C. Nasjleti ${ }^{2}$, \\ S. Kon ${ }^{3}$ and W. Castelli ${ }^{4}$ \\ 'Department of Periodontics, The University \\ of Michigan School of Dentistry, Ann Arbor. \\ Michigan, USA: ${ }^{2}$ Dental Research Programs, \\ Veterans Administration Medical Center, Ann \\ Arbor, Michingan, USA; ${ }^{3}$ Boston University, \\ School of Graduate Dentistry, Boston, Mass, \\ USA: 'Department of Anatomy, The University \\ of Michigan Medical School, Ann Arbor \\ Michigan, USA
}

\begin{abstract}
Smith B, Cafjesse R, Nasjleti $C$, Kon $S$ and Castelli W: Effects of citric acid and fibronectin and laminin application in treating periodontitis. I Clin Periodontol 1987. 14: $396-402$.
\end{abstract}

Abstract. To determine the effect on new connective tissue attachment of citric acid conditioning and fibronectin-laminin application in treating naturally occurring periodontitis, all 4 quadrants in each of 2 Beagle dogs were used. Each quadrant included: $\mathrm{P}_{2}, \mathrm{P}_{3}, \mathrm{P}_{4}$, and $\mathrm{M}_{1}$ teeth. 2 treatment modalities were employed and comparatively analyzed for differences in histological healing respponses at 120 days after surgery. The treatments were: (1) surgery (mucoperiosteal flaps) plus citric acid; (2) surgery plus citric acid followed by fibronectin-laminin application. After scaling and root planing, coronal and root surface reference notches were placed for histometric measurements. Following each of the randomly assigned treatments, flaps were sutured. After sacrifice, tissue blocks of treated areas were decalcified and serially cut, obtaining bucco-lingual and mesiodistal sections. Using a Filar micrometer, 5 distances were masured on the buccal aspect: (1) from root surface notch to alveolar bone crest; (2) from root surface notch to coronal extent of the cementum; (3) from root surface notch to apical extent of the junctional epithelium; 84) from free gingival margin to apical extent of junctional epithelium; (5) from the coronal notch to the alveolar bone crest. Results showed no differences among the 5 measurements between the 2 treatments tested. On mesio-distal sections, surface area determinations were made in the furcations, evaluating the space occupied by new connective tissue, with or without bone, or by epithelium. For this, images were digitized using a Zeiss IBAS Image analysis system with a $4 \mathrm{mB}$ of array processor memory coupled to a Newvicon TV camera and a microcomputer. Significant differences were found, with increased values for both regenerative connective tissue and bone when surgery plus citric acid was followed by fibronectin-laminin application. Often, these tissues filled completely furcation areas above root surface reference notches.
Key words: Citric acid - tibronectin - laminin. Accepted for publication 10 August 1986
Cells utilize high molecular weight glycoproteins to attach to the surrounding structures. Fibronectin is a glycoprotein intimately associated with the attachment of fibroblasts to collagen, various cells and their surrounding matrix (Kleinman, Klebe, Martin 1981). Laminin, on the other hand, is utilized by the epithelial cells for adhesion to different substrates and is a significant constituent of basement membranes (Terranova, Rohrbach \& Martin 1980).

Recently, the rôle that attachment proteins may play in new attachment procedures has received considerable attention (Terranova \& Martin 1981,
1982). In a previous communication, improvement in new connective tissue attachment to root surfaces of Beagle dogs affected with natural periodontitis occurred when the teeth were surgically treated using a modified Widman flap approach; the roots were demineralized and fibronectin was applied on the inner flap surface and on the roots (Caffesse et al. 1985).

Since laminin is used by the epithelial cells to bind to their substrate, it could be theorized that if laminin were applied to the cervical area of the root, close to the cementoenamel junction, it might enhance the adhesion of the epithelial cells to the tooth in that area, thus delaying their apical migration along the root surface

The purpose of the present study was to evaluate the use of a fibronectin and laminin combination in the treatment of naturally occurring periodontitis in Beagle dogs.

\section{Material and Methods}

2 6-year old female Beagle dogs, with intact dentition were selected from a closed Beagle colony at Laboratory Research Enterprises, Inc. in Kalamazoo, Michigan. Periodontal disease had re- 


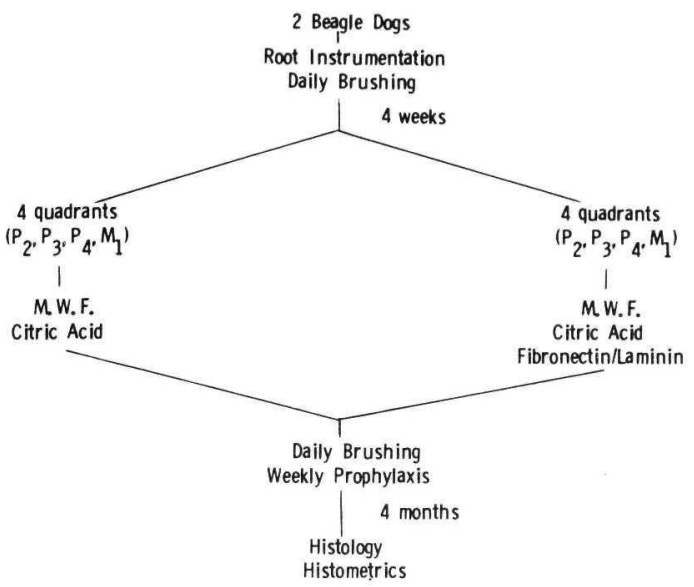

Fig, 1. Diagramatic representation of the protocol followed in the study.

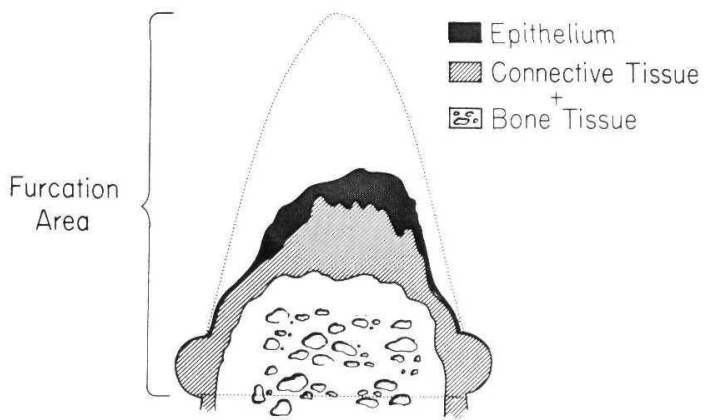

Fig. 2. Diagram showing the surface area determinations recorded in the furcation areas.

sulted in moderate to severe destruction of the supporting tissues, gingival recession and tooth mobility.

All teeth were scaled and root planed once. Daily brushing was carried out during the study (Fig. 1). 1 month after completion of root instrumentation, periodontal surgery was performed. A total of 8 quadrants were treated each including teeth $\mathrm{P}_{2}, \mathrm{P}_{3}, \mathrm{P}_{4}$ and $\mathrm{M}_{1}$. A split-mouth design was used with contralateral quadrants randomly assigned. mal interrupted 0000 braided black silk sutures. Suspensory sutures were also used in some cases. The other 2 quadrants were treated similarly, but after the application of citric acid and rinsing with sterile saline, fibronectin and laminin were applied in the following manner. The area was isolated with sterile gauze to prevent contamination with saliva. Fibronectin was then applied with a tuberculin syringe, bathing both the roots and the inner aspect of the flap. Immediately after, laminin was applied by painting the glycoprotein to the cemento-enamel junction areas and the most coronal part of the roots with a brush. Good flap adaptation was achieved by pressing the tissues against the roots and bone. Suturing was subsequently carried out. Fibronectin, of human origin, was purchased from Collaborative Research Inc., Waltham, Massachusetts. $1 \mathrm{ml}$ of sterile saline was added to the vial containing the $1.0 \mathrm{mg}$ of the lyophilized glycoprotein $30 \mathrm{~min}$ prior to its use. Laminin, extracted from the EHS tumor grown in mice was provided by Dr. Victor Terranova from the NIDR. It was kept frozen until needed, at which time it was allowed to thaw at room temperature. The concentration was $2.5 \mathrm{mg} / \mathrm{ml}$. Each glycoprotein was applied at the amount of $1.0 \mathrm{ml} /$ quadrant.

During surgery, 1 coronal notch and 1 radicular notch at the level of the alveolar crest, were made to be used as landmarks for histometric evaluation.

After surgery, daily brushing and weekly rubber cub prophylaxis were provided. 120 days later, the animals were sacrificed. The jaws were dissected, fixed, trimmed, decalcified in EDTA, washed, dehydrated, embedded in paraffin and sectioned at 5-6 intervals. Within each quadrant, alternate blocks were designated for either buccal-lingual, or mesial-distal sectioning, involving the furcation areas. The sections were stained with hematoxylin and eosin. Under a binocular light microscope, and using a Filar micrometer eyepiece* held parallel to the specimen surface (Nezwek et al. 1980), the following histometric measurements were recorded on the buccal-lingual sections.

(1) From the root surface notch to the alveolar bone crest. (2) From the root surface notch to with cotton pledgets for $3 \mathrm{~min}$. The area was then thoroughly rinsed with sterile saline. Repositioning of the flaps at or just coronal to the cemento-enamel junctions was achieved with interproxi-

2 quadrants per dog were treated surgically using a modified Widman flap procedure (Ramfjord \& Nissle 1974). thoroughly scaled and root planed, and then conditioned with a sterile solution of citric acid with a $\mathrm{pH}$ of 1.0 , applied

* Bausch and Lomb, Rochester, New York 14602, USA. 

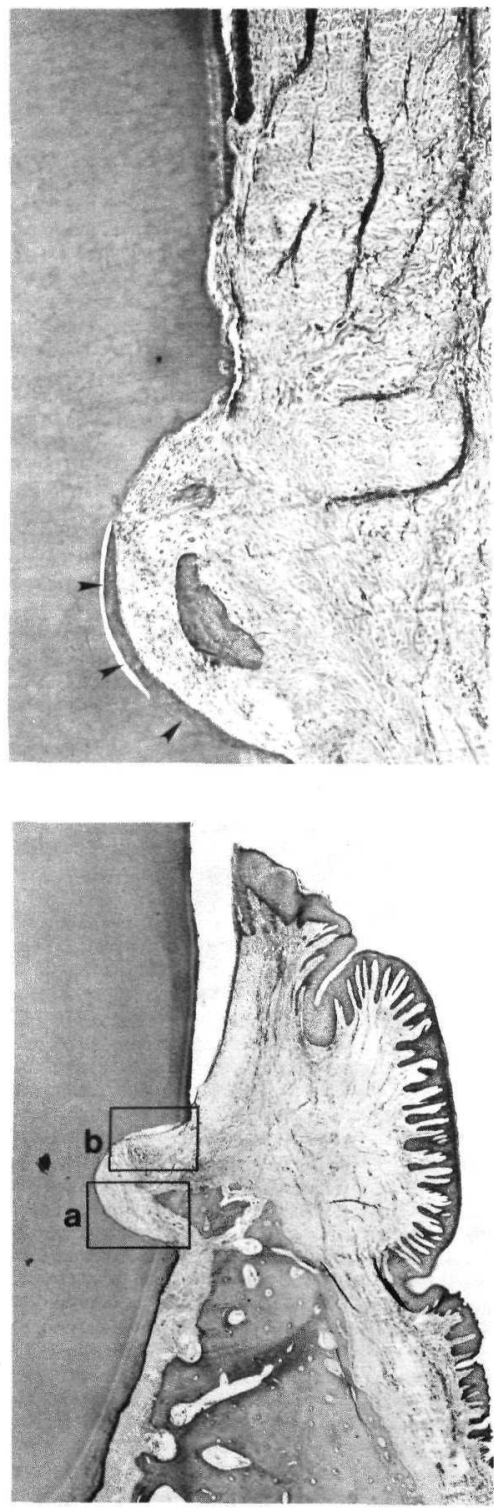

Fig. 3. Buccal-lingual section treated with citric acid. Observe the new connective tissue attachment with cementum deposition in the notch (arrows) and bone formation. $\mathrm{H} \& \mathrm{E} \times 40$.
Fig. 4. Buccal-lingual section treated with citric acid and fibronectin/laminin. Inset areas are shown at higher magnification. $\mathrm{H} \& \mathrm{E} \times 10$. the coronal extent of the newly formed cementum.

(3) From the root surface notch to the apical extent of the junctional epithelium.

(4) From the free gingival margin to the apical extent of the junctional epithelium.

(5) From the coronal notch to the alveolar bone crest.

Approximately 50 buccal-lingual sections per quadrant were measured. On the mesio-distal sections, surface area determinations $\left(\mathrm{mm}^{2}\right)$ relative to the furcations were made, evaluating: (1) the whole interradicular space, (2) the area occupied by epithelium, (3) the area filled with connective tissue, (4) the area filled with connective tissue and bone (Fig. 2). Images were digitized using a Zeiss image processing system with a $4 \mathrm{mB}$ of assay processor memory coupled to a Newvicon TV camera and a microcomputer. Approximately 15 mesio-buccal sections per quadrant were measured, corresponding to the furcation areas of $\mathrm{P}_{3}, \mathrm{P}_{4}$, and $\mathrm{M}_{1}$.

Mean values were obtained for the treated quadrants and the results statistically analyzed using two-sample $t$ tests.

\section{Results}

Operated areas healed uneventfully, but they all showed significant gingival recession.

On the buccal-lingual sections, both areas, those treated with citric acid (Fig. 3) and those treated with citric acid fibronectin and laminin (Fig. 4), showed similar healing. New connective tissue attachment was evident, including cementum deposition in the area of the notch, and some bone regeneration (Fig. 4a). However, a long junctional epithelium also developed, reaching in most instances the coronal aspect of the radicular notch (Fig. 4b). Some areas treated with fibronectin/laminin combination showed ankylosis. However, most of the ankylosed areas were located apical to the radicular notch (Fig. 5).

When the linear measurements recorded were analyzed, no significant differences between procedures were found (Table 1). However, both techniques gained some connective tissue attachment.

On the mesial-distal sections, the furcation areas were evaluated. The areas treated with citric acid only showed 

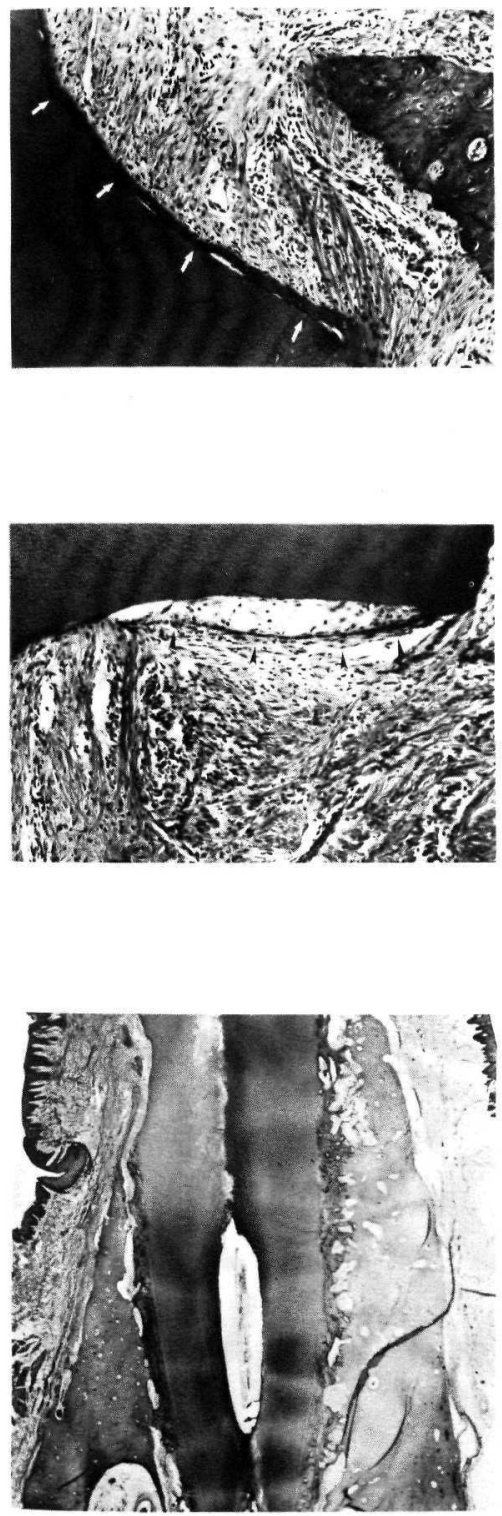

Fig, 4a. Higher magnification of Fig. 4. New connective tissue attachment is evident at the apical 2 3 of the notch, with new cementum (arrows) and bone formation. $\mathrm{H} \& \mathrm{E}$ $\times 100$.

Fig. 4b. Higher magnification of the coronal part of the notch seen in Fig. 4. An extension of the junctional epithelium is evident (arrows). H\&E $\times 100$.

Fig. 5. Buccal-lingual section treated with citric acid and fibronectin/laminin combination. Ankylosis is seen at the middle $1 / 3$ of the root. H\&E $\times 10$. more gingival recession than those treated with fibronectin-laminin. Connective tissue proliferated to the coronal level of the notches, and fiber attachment was evident with cementum deposition within the notch areas, and minimal bone growth was seen (Fig. 6). The areas which were treated with fibronectin-laminin combination depicted greater closure of the furcations (Fig. 7), with areas showing complete obliteration (Fig. 8). New connective tissue attachment, cementum deposition and bone growth were evident, with some teeth also showing different degrees of ankylosis.

The areas of the furcation filled with regenerated epithelium were similar for both procedures. However, the areas occupied with new connective tissue, including bone, demonstrated a significantly better response in the areas treated with fibronectin and laminin (Table 2).

\section{Discussion}

The present results confirm previous findings in the Beagle dog model relative to the effect of root conditioning with citric acid in new attachment procedures in natural periodontitis (Bogle et al. 1981). As reported earlier, those results could be improved by the application of fibronectin under the flap. bathing the gingival connective tissue and the demineralized roots (Caffesse et al. 1985).

The findings from the buccal-lingual sections showed that when laminin was used in addition to citric acid and fibronectin, there were no improvements of results beyong those obtained with the use of citric acid alone, in spite of the fact that fibronectin was also applied.

Although laminin was applied with a paintbrush to the cementoenamel junction area, it was impossible to prevent its apical seepage under the flap into the area previously covered with fibronectin. As a consequence, the result was a long junctional epithelium reaching the coronal border of the notch. It should be remembered that laminin was applied after fibronectin. It would appear that the application of laminin negated the beneficial effects of fibronectin in promoting new connective tissue attachment.

In the furcation areas, however, the findings were different. The distance from the cementoenamel junction to the furcation, and the protection that this 

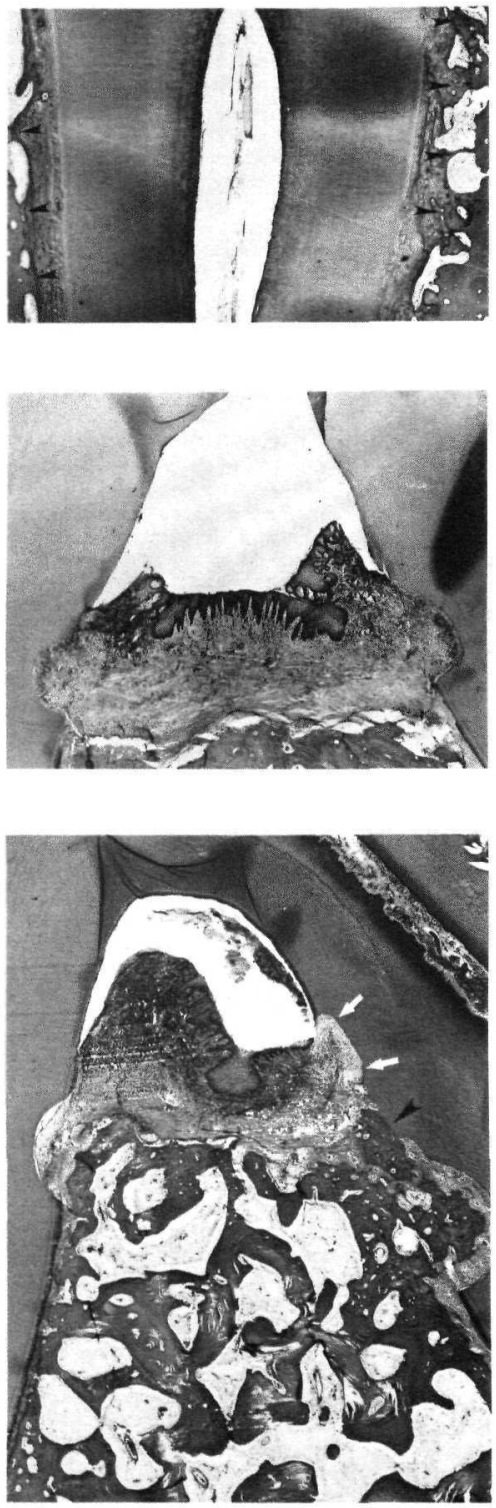

Fig. 7. Furcation area treated with citric acid and fibronectin/laminin combination. Epithelium, connective tissue and bone are seen coronal to the notches. The furcation is partially filled. Areas of ankylosis (black arrows) and arrested resorption (white arrows) are seen. $\mathrm{H} \& \mathrm{E} \times 25$. anatomical feature provided per se, made it improbable that laminin could leak deep enough so as to involve the entire furcation areas. Furthermore, it should be kept in mind that in spite of the gingival recession produced, the flaps were sutured at the cementoenamel junction away from the furcation areas. The degree of epithelial fill found in the furcation was similar with both treatments, which would indicate that this area was not affected by the applied laminin. This could be interpreted as due to the effect of the fibronectin application in areas where the laminin, applied afterwards, did not have the possibility to reach. Complete obliteration of some furcation areas was seen, with connective tissue attachment to new cementum, bone fill and even ankylotic areas. Most of the ankylosis was located apically to the notches; hence, it is difficult to conclude whether the treatment approach was responsible for these changes. However, reports indicate concern about the development of ankylosis after root conditioning (Magnusson et al. 1984). As shown by Karring et al. (1980) and Nyman et al. (1980), the source of cell repopulation during healing may be the factor determining the production of ankylosis.

It is evident that the intention of halting the apical migration of the junctional epithelium during healing by applying topical laminin on the cervical area of the root is not supported by the present findings. Furthermore, evidence seems to indicate that laminin may have a much more significant rôle in the pathogenesis of disease than in treatment (Boekeloo et al. 1986) However, the effect on healing of laminin alone, or with citric acid but without fibronectin, should be investigated.

\section{Conclusion}

Within the limits of the present investigation, it can be concluded that the use of a combination of fibronectin and laminin in new attachment procedures does not seem to be justified.

\section{Zusammenfassung}

Die Effekte der Zitronensäure sowie der Fibronektin und Laminin Applikation bei der Behandlung der Parodontitis

Zur Bestimmung des Effektes der Imprägnierung mit Zitronensäure, wie auch der Fibronektin-Lamininapplikation auf die Neubildung bindegeweblichen Attachments bei der Behandlung natürlich vorkommender Paro- 
Table 1 . Mean linear measurements (mm) on buccal-lingual sections; 2 sample $t$-tests

\begin{tabular}{lccccc}
\hline & Cittric acid & $\begin{array}{c}\text { Fibronectin } \\
\text { laminin }\end{array}$ & Difference & $\begin{array}{c}\text { Standard } \\
\text { deviations }\end{array}$ & Significance \\
\hline notch to bone & 0.220 & 0.160 & 0.060 & 0.133 & N.S. \\
notch to cementum & 3.082 & 2.465 & 0.617 & 2.08 & N.S. \\
notch to bottom junctional epithelium & 4.220 & 3.430 & 0.790 & 2.23 & N.S. \\
gingival margin to bottom junctional epithelium & 4.167 & 4.160 & 0.007 & 0.470 & N.S. \\
coronal notch to bone & 17.105 & 14.845 & 2.260 & 3.855 & N.S. \\
\hline
\end{tabular}
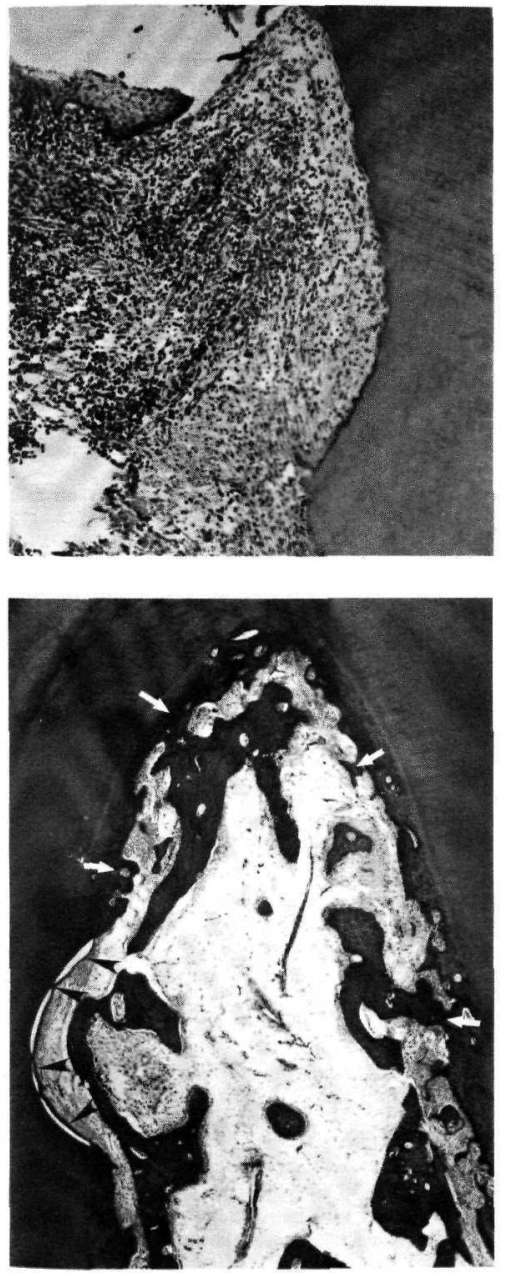

Fig. 7a. Higher magnification of area showing arrested resorption (white arrows) in Fig. 7. Eosinophilic material is seen deposited in areas of the surface and cells are aligning along it. Fibers are starting to achieve perpendicular arrangements at the apical end of the resorption bay. H\&E $\times 75$.

Fig. 8. Furcation area treated with citric acid and fibronectin/laminin. Complete obliteration of the area is seen. New cementum (black arrows) and connective tissue attachment are seen as well as ankylosis (white arrows). $\mathrm{H} \& \mathrm{E} \times 25$. dontitis, wurden an allen 4 Quadranten bei 2 Beagles-Hunden Versuche vorgenommen. Jeder Quadrant enthielt die Zähne: $P_{2}, P_{3}, P_{4}$ und $M_{1}$. Zwei Behandlungsformen wurden angewendet und dann, 120 Tage nach dem chirurgischen Eingriff, hinsichtlich ihrer Unterschiede bei der histologischen Heilung vergleichend analysiert. Folgende Behandlungsformen wurden miteinander verglichen: (1) Chirurgie (Schleimhautperiostlappen) mit Zitronensäurebehandlung; und (2) Chirurgie mit Zitronensäurebehandlung sowie daran anschliessend die Applikation von Fibronektin-Laminin. Zur histometrischen Auswertung wurden nach Zahnsteinentfernung und Wurzelglättung koronale Kerben angebracht. Nach jeder der, in der Reihenfolge zufällig bestimmten, Behandlungsmodifikationen wurden die Lappen suturiert. Nach dem Opfern der Versuchstiere wurden Gewebeblöcke der behandelten Regionen entkalkt und Serienschnitte so angefertigt, dass bukkale und mesio-distale Sektionen entstanden. Mit einem Filar-Mikrometer wurden in bukkalem Aspekt 5 Abstände vermessen: (1) Von der Wurzeloberflächenkerbe bis zur alveolaren Knochenleiste; (2) von der Wurzeloberflächenkerbe bis zum koronalen Beginn des Wurzelzementes; (3) von der Wurzeloberflächenkerbe bis zur apikalen Begrenzung des Saumepithels; (4) vom freien Zahnfleischsaum bis zu der apikalen Begrenzung des Saumepithels; (5) von der koronalen Kerbe bis zu der alveolaren Knochenleiste. Die Resultate zeigten keine Unterschiede zwischen den 5 Messstrecken der hier getesteten alternativen Behandlungsformen. Bei mesio-distalen Sektionen wurden die Bestimmungen in den Furkationen (Wurzelteilungsstellen) vorgenommen und hierbei der Zwischenraum beurteilt, der von dem neugebildeten Bindegewebe ausgefüllt wurde - mit oder ohne Knochen, oder auch durch Epithel. Technisch wurden Bilder mit dem Zeiss IBAS Bildanalysesystem digitalisiert - mit einem $4 \mathrm{mB}$ Kollektorgedächtnis an eine Newvicon TV-Kamera und an einen Mikrokomputor angeschlossen. Es wurden signifikante Unterschiede mit erhöhten Werten für regeneriertes Bindegewebe und Knochen dann konstatiert, wenn der chirurgische Eingriff und die Imprägnierung der Wurzeln mit Zitronensäure durch die Applikation von Fibronektin-Laminin vervollständigt worden war. Oft füllten die regenerierten Gewebe die Furkationsregionen bis oberhalb der Referenzkerben in den Wurzeloberflächen völlig aus. 
Table 2. Mean surface area determinations $\left(\mathrm{mm}^{2}\right)$ of furcation areas; 2 -sample $t$-tests

\begin{tabular}{|c|c|c|c|c|c|}
\hline & Citric acid & $\begin{array}{l}\text { Fibronectin } \\
\text { laminin }\end{array}$ & Difference & $\begin{array}{c}\text { Standard } \\
\text { deviations }\end{array}$ & Significance \\
\hline interradicular space & 13.035 & 12.087 & 0.948 & 2.48 & N.S. \\
\hline epithelium & 1.722 & 1.345 & 0.377 & 0.51 & N.S. \\
\hline connective tissue & 4.597 & 7.457 & 2.860 & 1.28 & 0.01 \\
\hline connective tissue plus bone & 5.182 & 8.137 & 2.955 & 1.48 & 0.02 \\
\hline
\end{tabular}

\section{Résumé}

Effets de l'acide citrique et de l'application de fibronectine et de laminine dans le traitement de la parodontite

$\mathrm{La}$ réalisation d'une nouvelle attache conjonctive suite a l'utilisation d'acide citrique et à l'application de fibronectine-laminine dans le traitement de la parodontite naturelle a été étudiée au niveau des quatre quadrants de deux chiens briquet. Chaque quadrant contenait les dents $P_{2}, P_{3}, P_{4}$ et $M_{1}$. La guérison histologique a été comparée 120 jours après la chirurgie utilisant deux modalités de traitement. Ces traitements étaient: 1) chirurgie (lambeaux mucopériostés) avec acide citrique et 2) chirurgie avec acide citrique puis application de fibronectine-laminine. Après détartrage et lissage radiculaire, des encoches coronaires et radiculaires de référence ont eté taillées pour les mesures histométriques ultérieures. A la suite de ces traitements les lambeaux ont été suturés. Après sacrifice, des biopsies completes des zones traitées ont été décalcifiées et coupées en série pour obtenir des coupes vestibulo-linguales et mésio-distales. En utilisant un micromètre filar, cinq distances ont été mesurees en vestibulaire: (1) de l'encoche radiculaire à la crête osseuse alvéolaire; (2) de l'encoche radiculaire à la limite coronaire du cément; (3) de l'encoche radiculaire a la limite apicale de l'épithélium de jonction; (4) de la gencive marginale à la limite apicale de l'épithélium de jonction; (5) de l'encoche coronaire à la crête osseuse alvéolaire. Les résultats n'ont montré aucune difference quant à ces cing mesures entre les deux traitements testés. Sur les coupes mésio-distales l'estimation des différentes surfaces a été effectuée dans les furcations, évaluant l'espace occupé par le tissu conjonctif, avec ou sans os, ou par l'épithélium. Ces images ont été chiffrées avec un système d'analyse d'image IBAS Zeiss avec mémoire, caméra et microordinateur. Des différences significatives ont été trouvées avec augmentation des valeurs pour le nouveau tissu conjonctif et l'os lorsque la chirurgie avec acide citrique était suivie d'une application de fibronectine-laminine. Souvent ces

tissus remplissaient complètement les zones de la furcation au-dessus des encoches radiculaires de référence.

\section{References}

Boekeloo, S., Smith, B., Syed, S. \& Huard, T. (1986) Basement membrane laminin: Putative role in pathophysiology of periodontal disease. Journal of Dental Research $\mathbf{6 5}, 353$, abstract \# 1654 .

Bogle, G., Adams, D., Crigger, M., Klinge, B. \& Egelberg, J. (1981) New attachment after surgical treatment and acid conditioning of rrots in naturally occurring periodontal disease in dogs. Journal of Periodontal Research 16, 130-133.

Caffesse, R. G., Holden, M. J., Kon, S. \& Nasjleti, C. e. (1985) The effect of citric acid and fibronectin application on healing following surgical treatment of naturally occurring periodontal disease in Beagle dogs. Journal of Clinical Periodontology 12, 578-590.

Karring, T., Nyman, S. \& Lindhe, J. (1980) Healing following implantation of periodontitis affected roots into bone tissue. Journal of Clinical Periodontoloy 7, 96-105.

Kleinman, H., Klebe, R. \& Martin, G. (1981) Role of collagenous matrices in the adhesion and growth of cells. Journal of Cell Biology 88, 473-485.

Magnusson, I., Claffey, N., Bogle, G., Crigger, M., Garrett, S. \& Egelberg, J. (1984) Root resorption following periodontal flap procedures in monkeys. Journal of Dental Research 63,211 , abstract $\# 457$.

Nezwek, R. A., Caffesse, R. G., Bergenholtz, A. \& Nasjleti, C. E. (1980) Connective tissue response to periodontal dressings. Journal of Periodontology 51, 521-529.

Nyman, S., Karring, T., Lindhe, J. \& Planten, S. (1980) Healing following implantation of periodontitis - affected roots into gingival connective tissue. Journal of clinical Periodontology 7, 394 401.

Ramfjord, S. P. \& Nissle, R. R. (1974) The modified Widman flap. Journal of Periodontology 45, 601-607.

Terranova, V., Rohrbach, D. \& Martin G. (1980) Role of laminin in the attachment of PAM212 (Epithelial) cells to basement membrane collagen. Cell 22, 719-726.

Terranova, V. \& Martin, G. (1981) A possible role for attachment proteins in periodontal reattachment. Journal of Dental Research 60, 390, abstract \# 320 .

Terranova, V. \& Martin, G. (1982) Molecular factors determining gingival tissue interactions with tooth structure. Journal of Periodontal Research 17, 530-533.

Address:

B. Smith

Department of Periodontics

School of Dentistry

The University of Michigan

Ann Arbor, MI 48109

USA 
This document is a scanned copy of a printed document. No warranty is given about the accuracy of the copy. Users should refer to the original published version of the material. 